\title{
The Impact of Phonics Instruction on Pre-school Learners' Development in English Language Course
}

\author{
Huanhuan $\operatorname{Ren}^{1, a^{*}}$, Chi Ma ${ }^{2, b}$ \\ ${ }^{1}$ Teaching and Research Institute of Foreign Languages, Bohai University, Jinzhou 121013, China \\ 2 Jinzhou Institute of Forestry Research, Jinzhou Forestry Bureau, Jinzhou 121013, China \\ arenhuanhuan2014@163.com, ${ }^{\mathrm{b}}$ machi2014@tom.com
}

Keywords: Phonics; Pre-school learners; English language

\begin{abstract}
Phonics is one important part of language learning and it contributes to language literacy through involving learners understanding the relationship between letter form and speech sound. It's made evident that younger learners are shown the ability to learn a foreign language in many researches and thereby phonics should be taught systematically as part of a balanced and integrated English language program. It's found that the impact of phonics instruction on development of pre-school English language learners could be reflected and denoted in four parts or areas of language learning, i.e. pronunciation development of pre-school learners, spelling development of pre-school learners, vocabulary development of pre-school learners and reading development of pre-school learners. It's hoped that this research provides a useful reference for future phonics instruction practice among younger English language students.
\end{abstract}

\section{Introduction}

More than a century of debate has occurred over whether English phonics should or should not be used in teaching beginning reading due to the complexity of written English [1]. Since the turn of the 20th century, phonics has been widely used in primary education and in teaching literacy throughout the world [1]. Thus, what benefits may accrue from learning phonics in the first few years of life? Should phonic awareness and instruction be integrated in English language learning program among pre-school learner? In this thesis, we try to offer advice on why to teach phonics to pre-school learners and figure out the impact of phonics instruction on pre-school learners' development in English language learning. This paper is a summary of this research work, which hopefully provides a useful reference for future phonics instruction practice among young language students.

\section{The Description and Development of Phonics Instruction}

Concepts of Phonics. What is phonics? Two central and key concepts constitute the idea of phonics: grapheme and phoneme. Grapheme is a written symbol that is used to represent speech, while phoneme is one of a small set of speech sounds that are distinguished by the speakers of a particular language. Specifically speaking, grapheme and phoneme represent respectively letters or groups of letters and their pronunciations. The core content of phonics, in somewhat simpler terms, is the relationship between word form and sound, or say, letter and speech sound. According to Allen, phonics refers to the set of relationships between sounds and how they can be represented by letters of the alphabet in print; that is, the sound-symbol relationships or grapho-phonics [2]. Yoop who held the same viewpoint of Allen, pointed that phonics is view as a method which stresses the letter-sound correspondences connection in alphabetic orthographies [3]. As the example given by Groff, phonics is information about how the speech sounds in oral language (e.g., /b/-/ ă /-/t/) are represented by letters of alphabet (e.g., bat) [4]. As to phonics instruction, Hsu viewed that that phonics instruction referred to all the teaching and approaches used to present or introduce the letter-sound correspondence relationship [5]. To sum up, all above mentioned definitions focus on a body of knowledge about letters and sounds, especially the letter-sound correspondence connection. 
Differences between IPA and Phonics. The phonics is easily confused with the International Phonetic Alphabet (IPA), which is widely used among English learners. The IPA was devised by the International Phonetic Association as a standardized representation of the sounds of spoken language. It's an alphabetic system of phonetic notation based primarily on the Latin alphabet. That is, it was devised to represent the sounds heard when words are pronounced. The general principle of the IPA is to provide one letter for each distinctive sound (speech segment). The abstractness of the symbols causes a learning burden to the students. And teaching two sets of similar symbols during an early stage of language learning will cause confusion and produce a sense of frustration for students [6]. Furthermore, students who rely on the IPA symbols will fail to develop the decoding process and feel helpless in sounding out new or unfamiliar words when there is no phonetic symbols transcription [6]. As Curtis stated, learners don't have to memorize vocabulary and spell the words, because they have been given a tool that can be used over and over again while reading and writing [7]. The phonics principles can be wildly applied to help children with spelling and reading, which is much better than rote memorization and guesswork[6]. To sum up, compared with the IPA symbols, phonics seems to have much more advantages. In practice, IPA can be related to phonics through helping crystallized some confusing word pronunciation and remind learners to read words more accurately.

Development of Phonics Instruction. Phonics exerts considerable influence on contemporary society and the most of the society begin to pay attention to phonics and actively participate in the educational reform. In generally terms, there are several different methods for teaching phonics: synthetic phonics, analytic phonics and analogy phonics. Many researchers are favor of the synthetic phonics instruction, which uses a part-to-whole approach to learn letter-sound (grapheme-phoneme) relationships in a clearly defined incremental sequence, and it's found that synthetic phonics instruction can bring about more productive reading, spelling and great phonemic awareness than analytic phonics instruction[8]. Overall, phonics is being preceded in a great many of English-speaking countries, such as Canada, Australia, UK, Singapore later on. Children in those English-speaking countries usually started to receive phonics training when they were in the elementary school. And it is the dominant method to teach and learn the pronunciation and words[9]. Owing to the education reform of North America, phonics method as a new model of second language teaching has become the prevailing teaching method since the 1990s[9]. It's found that researchers and educators discovered phonics instruction as an English teaching instruction not only for young native speakers but also for EFL learners. In light of a large body of research on the effectiveness of phonics in EFL learning, phonics instruction was largely embraced by EFL learners in Asian countries such as China.

\section{Theoretical Basis of Phonics Instruction for Pre-school English Language Learners}

English Teaching for Younger Learners. There is a popular belief that children as EFL or ESL learners are superior to adults [10], that is, the younger the learner, the quicker the learning process and the better the outcomes. A great amount of scholars hold that the second language learning in the country should begin as early as the child is four. At the same time, the claim of an optimal period for EFL acquisition also received different augments. As Harley and Wang have argued, more mature learners are usually capable of making faster initial progress in acquiring the grammatical and lexical components of an L2 (or EFL) due to their higher level of cognitive development and greater analytical abilities[11]. Although it has shown a lack of direct correlation between an earlier start and more successful and rapid EFL development in some classroom-based studies, younger learners are shown the ability to learn a foreign language in many researches. It's found that, attention, short-term memory, and long-term memory are developing between the ages of 2 and 5[12]. And it's concurred that younger learners are particularly savvy at capturing and repeating speech sounds of a foreign language. And better mastering the pronunciation of a foreign language not only promotes language proficiency in other language areas, but also enhances motivation and interest of learners to pursue more learning on it. 
Phonics Teaching among Pre-school Learners. There are some truth about the idea of instructing phonics among pre-school learners. As Gimson stated in his book, in order to speak any language, one needs to learn almost $100 \%$ of its pronunciation, $50 \%-90 \%$ of its grammar and about $1 \%$ of its vocabulary [13]. We can see phonics is one important part of language learning. Moreover, letter-sound correspondences are arbitrary and therefore difficult to discover without explicit teaching. Left to chance or inference alone, many students would acquire phonics knowledge too slowly or fail to learn it at all [14]. Phonics instruction may be especially difficult in English, since English has the most difficult spelling of any Western language. Phonics teaching needs to begin early in kindergarten and be provided in short, regular, fast-paced teaching sessions (around 20 minutes overall with time distributed as best judged by the teacher) [14]. For learners to make sense of phonics teaching, students need to understand that a word is made up of a series of discrete sounds, and teaching phonics is an effective way to significantly influence the rate at which students successfully acquires phonics knowledge and skills. Among pre-school learners, phonic awareness and instruction need to be integrated in their learning courses. In sum, a majority of researchers hold that there is a critical need for phonics learning, and the first few years of life is the crucial time to learn phonic if individuals are presented with adequate stimuli.

\section{The Impact of Phonics Instruction on Development of Pre-school English Language Learners}

Pronunciation Development of Pre-school Learners. Why do pre-school learners learn phonics? Many scholars endorse phonics among language learners because learners can accurately and effortlessly master pronunciation of a new foreign language through phonics practice. Phonics provides the child with a method for relating letters to sounds so that learners can pronounce an unfamiliar printed word, and finally understand it. In other words, a body of knowledge about the letters and sounds correspondence relationships help pupils pronounce the words by learning the sounds of letters, letter groups, and especially syllable. In practice, phonics is regarded as one of the most powerful tools in improving pronunciation as phonics is dealing with all single letter sounds combined with letter names. The idea is also revealed in Durkin' work where phonics is considered as a series of knowledge about relationship between letters and speech sounds which are used to help readers recognize the pronunciation of words unknown in their written form[15]. Explicit phonics teaching requires teachers to clearly and consistently enunciate the sounds they are teaching, and students need to understand that a word is made up of a series of discrete sounds in order for them to make sense of phonics teaching and pronunciation learning. From above, we can see pronunciation development of pre-school learners can be enhanced if pre-school learners engage themselves in phonics knowledge and practice phonics in foreign langue learning.

Spelling Development of Pre-school Learners. Besides the advance in language pronunciation through mastering letter-sound correspondence, spelling development is also part of the appeal of phonics instruction among pre-school learners. On one hand, pre-school learners are taught with correspondences between graphemes in written language and phonemes in spoken language, and on the other, these correspondences instructed in English language course are supposed to be used for the work of words spelling. Just as Stahl put, phonics is an approach to help children learn how to decode words [16]. In the process of decoding words, teachers are required to take the lead on guiding children manipulate sounds in written words through spelling tasks, pointing out patterns in similarly spelled words, or anything else which helps children learn about orthographic patterns in written language. So this phonics training can facilitate the improvement of their ability to spell new words. Over time, spelling abilities of pre-school learners can be improved. To sum up, phonic training and practice process is conducive to the knowledge of spelling for each new word, and pre-school learners can become better at spelling words if teachers guide students to grasp the letter-sound correspondence relationship in phonics learning.

Vocabulary Development of Pre-school Learners. It's concurred that pronunciation and spelling are two components when learning a new foreign language word, but that's not the whole 
picture of learning a new word. Word meaning is supposed to be taken into account for pre-school learners who are learning an unknown word. Actually both pre-school learners and non-pre-school learners are facing with language difficulties in memorizing a large amount of new words under traditional teaching model. Younger learners are provided with the advantage of mastering a large body of vocabulary within short time through phonics activities as learning language is still something of curiosity and concern. Drawing more heavily on the phonics knowledge, learners can have a good command of new words through making analogy from known words to new words. The prerequisite is that learners have been equipped with phonetic knowledge and other decoding approaches. Effective phonics teaching supports students to readily recognize and produce familiar words accurately and effortlessly and to identify and produce words that are new to them. Analogy phonics help students to use parts of written words they already know to identify new words. In brief, it's proved that vocabulary development of pre-school learners can be largely fostered through effective phonics learning by younger foreign language learners.

Reading Development of Pre-school Learners. Instructors embrace phonics in the classroom based on the promise that it can have an positive effect on reading comprehensive abilities of younger learners. In the course of phonics teaching, as children start to get the hang of it, they begin to selfteach and need to read a lot to consolidate their skills, that is, to develop effortless reading and focus more on comprehending the text [17]. That's why some researchers employ phonics as a method of reading instruction that breaks language down into its simple components. Stephen shared the same idea that children learn the sounds of individual letters first, then the sounds of letters in combination and in simple words. Those easy reading exercises with controlled vocabulary consolidated the process [18]. And Heilman also stated that "phonics is not a method of teaching reading but is an essential ingredient of reading instruction.[19]" We can see that phonics is highly related with reading and phonics is a fundamental part of learning to read the English language. No doubt, National Inquiry into the Teaching of Literacy pushed by Australia states that teachers provide systematic, direct and explicit phonics instruction so that children master the essential alphabetic code-breaking skills required for foundational reading proficiency [20]. To sum up, there seems to be universal agreement that some of the more obvious benefits of phonics is the development of reading ability because developing automatic word recognition may support and enhance students' comprehension skills.

\section{Conclusion}

It has been argued that phonics is one important part of language learning, as it contributes to language literacy through involving learners understanding that letters and combinations of letters make up particular sounds and words. It's made evident that younger learners are shown the ability to learn a foreign language in many researches and thereby phonics should be taught systematically as part of a balanced and integrated foreign language program. It's found that the impact of phonics instruction on development of pre-school English language learners could be reflected and denoted in four parts or areas of language learning, i.e. pronunciation development of pre-school learners, spelling development of pre-school learners, vocabulary development of pre-school learners and reading development of pre-school learners. It's hoped that this research provides a useful reference for future phonics instruction practice among young language students.

\section{Acknowledgements}

This work is part of the project of On Cultivating and Developing Liaoning Scientific Foreign Language Talents with View to Bourdieu' Theory, the project of On Establishing Generative Mechanism of EFL Autonomous Learning Behaviors and Strengthening Development of Learning Field in Ubiquitous Learning Space, and the project of On Constructing Mechanism and Strategies for College English Autonomous Learning Abilities via Mobile Multimedia. This research was supported by the fund of Liaoning Planning of Philosophy and Social Science (Project No. 
L16CYY001), the fund of Liaoning Provincial Federation Social Science Circles (Project No. 20171slktyb-019), and the fund of the Thirteenth Five-Year Plan of Education Sciences of Liaoning Province (Project No. JG16DB013).

\section{References}

[1] Phonics. Retrieved from https://en.wikipedia.org/wiki/Phonics\#History_and_controversy.

[2] R. Allen, First English Phonics, Beijing: Peking University Press, 2008.

[3] H. K. Yopp, R. H. Yopp, Supporting phonemic awareness development in the classroom, The Reading Teacher, (54) 2000.

[4] P. Groff, Modern phonics instruction, Retrieved 10 December, 2010 from the information on ERIC Document Reproduction Service No. ED 328900, 1989.

[5] L. H. Hsu, A Study on Phonics and Phonetic Symbols in ESL: [Unpublished master's thesis ], National Taiwan Normal University, 2000.

[6] C. Zhang, A Study on the Application of Phonics in English Tutoring in Primary Schools, Hunan Normal University, 2013.

[7] M. E. Curtis, Development of the components of reading, Journal of Educational Psychology, (72) 1980.

[8] M. J. Adams, M. Bruck, Resolving the "Great Debate", American Educator, (2) 1995.

[9] Z. Yu, An Application Study of Phonics in English Phonology and Vocabulary Teaching in Primary School, Jiangxi Normal University, 2011.

[10] T. Scovel, "The younger, the better" myth and bilingual education. In: González R. D, Melis I, editors. Language Ideologies. Critical Perspectives on the Official English Movement. Mahwah, NJ: Lawrence Erlbaum Associates, 2000.

[11] B. Harley, W. Wang, 'The critical period hypothesis: where are we now?' in A. M. B. de Groot and J. F. Kroll (eds.). Tutorials in Bilingualism. Psycholinguistic Perspectives, Mahwah, NJ: Lawrence Erlbaum Associates.

[12] Cognitive Stages for Child Development, Retrieved from the information on http://www.learningrx.com/cognitive-stages-for-child-development.htm

[13] A. C. Gimson, An Introduction to the Pronunciation of English, 3rd ed.London: Edward Arnold, 1980.

[14] Literacy Teaching Guide: Phonics, Sydney, New South Wales: NSW Department of Education and Training Learning and Development, Retrieved from the information on https://my.vanderbilt.edu/specialeducationinduction/files/2011/09/1-Literacy-teaching-guide-ph onics.pdf, 2009.

[15]D. Durkin, Teaching them to read, Boston: Allyn and Bacon, (190) 1993.

[16] S. A. Stahl, Teaching phonics and phonological awareness. In S. B. Nenman and D. K. Dickinson (Eds.), Handbook of early literacy research, The United States of America: The Guilford Press, 2002.

[17] J. Rose, Independent review of the teaching of early reading, Department for Education and Skills, UK, 2006.

[18] S. Glazier, Random House Word Menu, Random House, Inc.2003

[19] A. W. Heilman, Phonics in proper perspectives, Columbus: Merrill, 1985. 
[20] National Inquiry into the Teaching of Literacy, Teaching Reading, Report and Recommendations, Australian Government, Department of Education, Science and Training, Canberra, 2005. 